\title{
CHROMATIC ANALYSIS OF THE BYZANTINE FACE
}

\author{
Grecu Dorin \\ Senior Lecturer, Phd, University of Piteşti, Romania, dorin_grecuro@yahoo.com
}

\begin{abstract}
The present paper is focusing on a detailed analysis of the chromatic Byzantine face, from an esthetic and technical perspective.

From an esthetic point of view, we can distinguish two directions in the chromatics of the Byzantine face: the first one can easily be observed in the Paleologos period, and the second one is reflected in the paintings originating from Crete, due to the famous painter Teofan of Crete (Cretanul). The major chromatic differences lie in the colour accents used during the two periods. The chromatic analysis focuses both on tint fusions and on the chemical composition of the pigments used in the making of the respective tints. Thus, we can compare each accent of the face originating in the Paleologos period with its correspondent from Crete, meaning: the proplasma, the semi-tint, the flesh colour, and the lights. We can distinguish visible differences that emerge in the level of proplasma or of the tint. (The background of the face)

If in the Paleologos period, the face proplasma was shaded green, in the paintings originating in Crete, it changes into delicate, siena shades. First, the detailed and optic analysis is based on the comparison of the traditional recipes, and then it is scientifically based on a sample of specific pigments, used in paintings originating in the two periods. The pigments are spectrometrically analyzed through X-ray fluorescence, constantly comparing the results. Thus, it results that the green proplasma (Paleologos period) is obtained by mixing black with green (chromium green oxide, Cr203) and ochre (natural, mineral pigments, earth or clay with a certain content of hydrated iron oxide, $\mathrm{Fe} 203 \mathrm{n} \mathrm{H2O}$ ). And the proplasmas of the faces in the paintings originating in Crete are obtained from clay substances called siena. The next accents (the flesh colour and lights) are pure ochres, afterwards being mixed with white. Over these two accents, we can identify a shift in the faces painted by Teofan of Crete. He uses the same proplasmas, but, in some paintings, he removes the flesh colour (the ochre), the lights being directly applied over the proplasma. This method is unique in the history of Byzantine painting, Teofan, thus, creating a true light Impressionism.

In conclusion, this paper, by following the traditional recipes embedded deep into the Byzantine painting, manages to create optic analysis of the chromatics of the Byzantine faces, strengthening them with the chemical analysis of the used pigments. Thus, we witness the emergence of two directions: the Paleologos period and the one dominated by Crete art, with a third direction, isolated and unique, created by Teofan of Crete.
\end{abstract}

Keywords: Byzantine face, chromatics, colour, pigments. 


\section{INTRODUCTION}

Byzantine painting witnessed several stages of development, there even being the possibility to outline certain original manners (schools) that correspond, to a large extent, with the main historical periods of the Byzantine Empire. From a chronological and social point of view, Byzantine art includes a first period that begins with early church and lasts until the famous Macedonian dynasty, comprising the age of Justinian (the golden age). In this first period, Byzantine architecture is beginning to assume its shape, the most glaring example of it being the construction of Hagia Sophia, an architectural landmark, a set of methods and ideals in art. In the painting produced in this period, the mosaic is the main technique that adorns the sumptuous church buildings (Delvoye, 1976, p. 6).

Macedonian painting is thought to represent the climax of the Byzantine Empire or the "second golden age" after the age of Justinian. In the work "NicephorePhocas si l'Epopeebyzantine", the French Byzantinist G. Schlumberger made known the history of this era. He divides the history of the Macedonian dynasty into two periods.The first period was between 867 and 1025 - marking the year of Emperor Basil Il's death.The second period was between 1025 and 1056, ending with the death of Empress Theodora, the last representative of this dynasty (Schlumberger, Paris, p.498-536).

The Macedonian Byzantium exterted an influence throughout Europe. As an illustrative evidence of this influence stand the frescoes painted in the second half of the ninth century and the beginning of the tenth century in the churches of Rome: San Clemente and Santa Maria di Gradellis, or Church of the Holy Martyrs from Cimitile(Văetis, 2008,p. 16).

The mosaics bear the seal of the sense of noble grace, the suppleness of drawing, the freshness and buoyancy of the colouring, the finesse of patterns, the care for the decorative line" (Văetis, 2008, p. 55). All these elements make the picture of this period take shape in a well-defined style of painting also called Macedonian painting.

Comnenian painting was created during the Comnenian Dynasty (1081-1206) and continued the line of Macedonian painting.

In developing the iconographic program, this period is characterised by the representation of the theme of the Pantocrator in the central dome"(Văetis, 2008, p. 43).

Palaiologan painting was born once with Michael VIII Palaiologos - the Restorer, the last great reign in the history of Byzantium (http://www.crestinortodox.ro/carti-ortodoxe/istoria-bizantului/paleologii-cadereaimperiului-bizantin-80681.html).

In this period, Byzantine painting reaches its peak, detaching from others through the refinement and consistency of styling. An aesthetic feature of the compositions is represented by the intensification of lights, tones and values of the faces, clothes, architecture and their spread on large areas ${ }^{1}$. The clarity of lights on clothes and faces is alternated with extremely refined passages to some parts of these compositional elements. By removing the precious stones from the mosaic, for economic reasons, the artist tried to fill the lush void with lights for compositional charging and to obtain an image as luxurious. In Palaiologanpainting, the myriad of lights on clothes, faces and other compositional elements sought to preserve the bright and luxurious image from the previous periods. The art commanded by the emperors of the empire gave in to that commanded by the nobles of the Empire, so the sumptuous great is replaced by the imprint of the artist who is growing ever more present in the work.

Thus, Palaiologanart becomes a synthesis between the two spiritual forces that dominated Byzantium: classicism and mysticism (Vasiliev, 2010, p. 67).

Cretan painting was represented by Teophanes the Cretan, the head of the Cretan school who worked in the regions of Macedonia and Thrace, but especially at Mount Athos and Meteora.

(http://www.crestinortodox.ro/liturgica/pictura/teofan-cretanul-calugar-pictor-98193.html).

A special case occurs in Russia through the arrival from Constantinople of Theophanes the Greek. "At Novgorod, enjoying more freedom in composition and execution, he could unleash his violent and passionate temper...his faces were sometimes compared with the photographic negatives"(http://www.crestinortodox.ro/religie/teofan-grecul-iconarul-celor-nevazute-98774.html.)

\footnotetext{
${ }^{1}$ In Palaiologanpainting, lights, especially the ones on the garments, are coloured (cooled) from the proplasmatill the lastlight. Dueto this, onecan also speak of tones, notonly of values of Byzantinelights.
} 
His paintings look nothing like the contemporary ones. He comes to substitute certain stages of the technique of Byzantine painting, such as placing lights directly over the proplasma, except for the skin tone.

\section{THE STYLISTICAL ANALYSIS OF THE CHROMATICS OF THE BYZANTINE FACE}
a. Proplasma
b.Skin tone
c.First lightd.Final stage

Fig.1.The main steps in painting the Byzantine face. Contemporary icon painted by LiviuDumitrescu
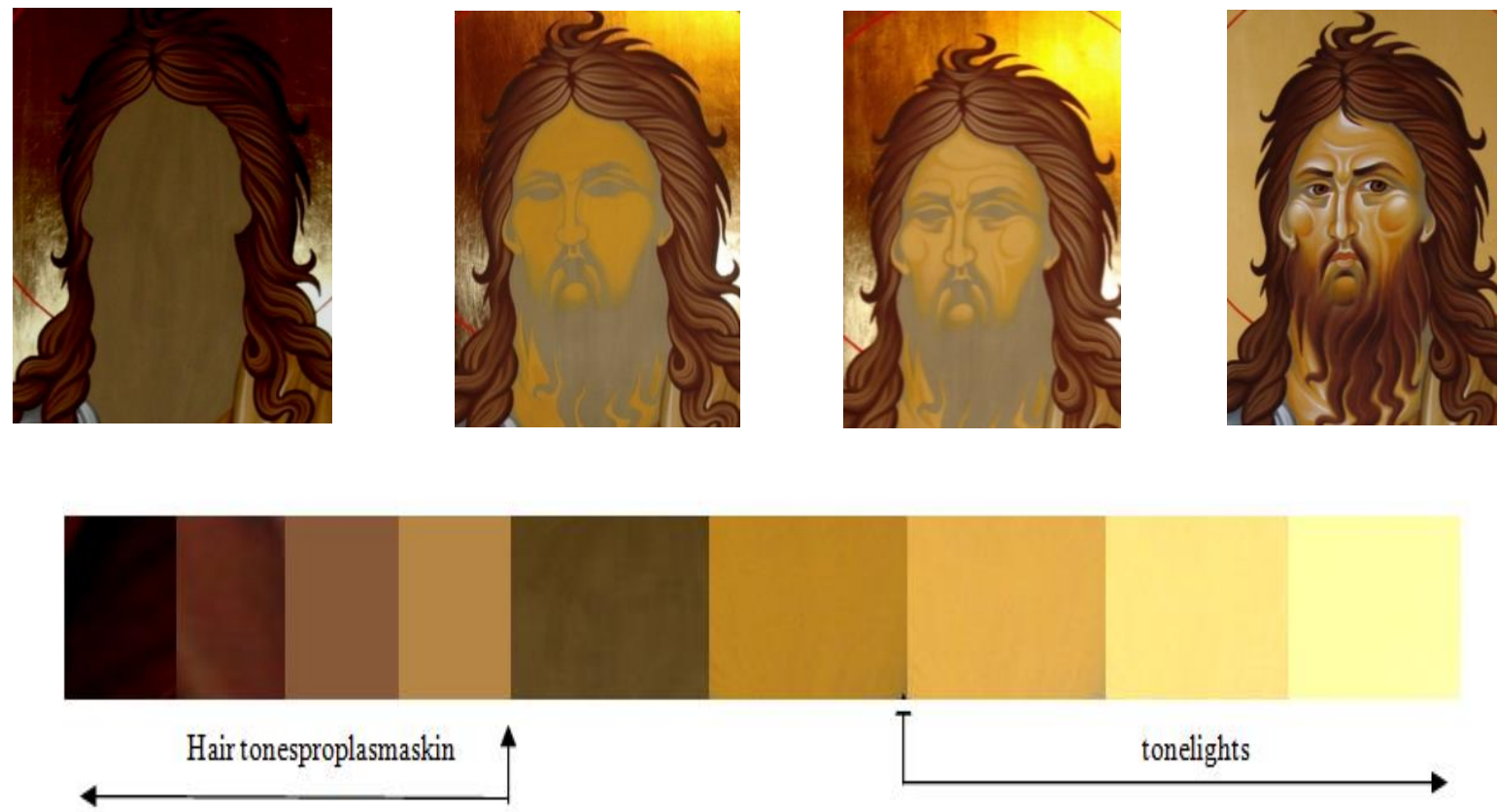

Fig 2.The colour tones used for faces

When painting the Byzantine face, the optical effect of the molding is obtained by the overlapping of the colour layers. The essence of the technique of painting a Byzantine-styled face lies inthe achievement of these semitransparent or, sometimes, opaque layers. Thus, deep shadows and overlapping layers of light are obtained, which are barely perceivable. The outline is precise, the drawing having great importance (Sendler, 2005, p. 251).

The painter must create a harmony of colours that must fit within the boundaries of a canon, a fact that requires abundant experience in the field. To paint the face, the first step would be that of laying out a darkcoloured proplasma, a mixture of the colours black, green and earthy. Then an ocherwould be added in the proplasma for the first modeling. The areas that had to be lit were, each time, diminished in size(Sendler, 2005, p. 252).

Whenanalyzing the face from the Byzantine painting, two technical principles to brighten faces are to be highlighted. The first one constitutes the adding of skin tone and lights by colour spot and the second by fine hatching blurred towards the edges.But, no matter what the period, the area or the school might have been, there was only one technique, i.e. the tone overlap. By this tone overlap a value overlap was aimed at. Thus, always starting from dark values, one will reach lighter ones, up to the value of white.
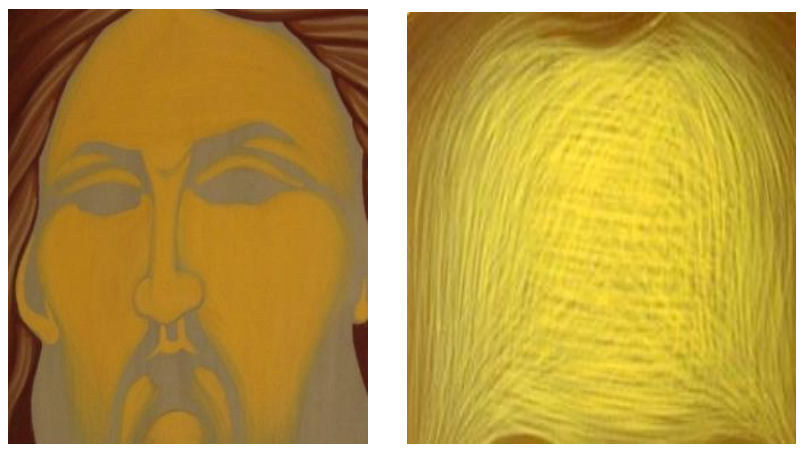

Fig.3. Applyingskin tonethroughcolourspot and throughhatches. Iconpainted by Liviu Dumitrescu 


\subsection{The Proplasma}

By"proplasma" one understands the dark value tone that serves as background for faces and areas with visibleskin tone. It represents the colour over whichthe light tones and shade accents are overlaid and, after their settlement, it will become itself a shadow for the respective face or area (Fig.1.a).

For this proplasma, the masters in the style formulated precise recipes throughout the history of Byzantine painting, some of these recipes being preserved till this day. The most important one is the recipe formulated by the painter Manuel Panselinos ${ }^{2}$, preserved and transmitted by Dionysius of Fourna as follows: "Put lead white, ocher, green earth that is used to work on the wall [and black], and powder them all together. Then apply this background or proplasma, wherever you have to paintflesh colour [but mind you do not make it yellow or green] (Dionysius of Fourna, 2000, p. 36).

In other periods and other areas,other proplasmawas used, depending on such factors as the existing pigments, the need to obtain the image and the perceptible symbolism in the respective area and age.

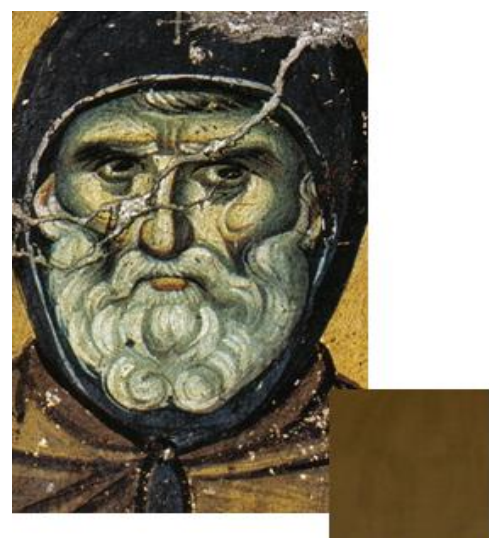

Fig. 4. Palaeologan proplasma

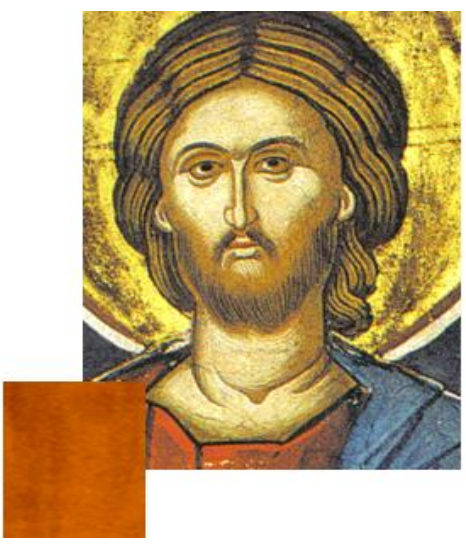

Cretan proplasma

Consequently, two major trends are discernible; one of them is this gray-green proplasma, known as Panselinos'sproplasma, or the Palaiologanproplasma. The second is the proplasma of the Cretan School, with a shade of warm, grayed sienna. It will without doubt be a dark colour that will serve as a shadow for some areas where it is needed.

\subsection{Skin Colour}

Skin colourrepresents the tone to be used when rendering the colour of the human skin. It is in a practical sense the tone that gives the natural colour of the character in question. Given that the proplasma does not remain in large areas, the skin colour represents the basic colour of faces or other body parts that are visible (Fig.1.b.).All descriptions from Byzantine painting manuals lead to the idea that this tone should be close to a warm ocher. Yellow ocher is the main pigment that is included in the composition of the skin tone, a"mixture called sankir"(Sendler, 2005, p. 242).

CenninoCennini mentions the following related to the preparation and spreadof theskin colour: "First take a little dish; put a little lime white into it, a little bit will do, and a little light cinabrese, about equal parts. Temper them quite thin with clear water. With the aforesaid bristle brush, soft, and well squeezed with your fingers, go over the face, when you have got it indicated with terre-verte; and with this pink touch in the lips, and the 'apples' of the cheeks. My master used to put these 'apples' more toward the ear than toward the nose, because they help to give relief to the face. And soften these 'apples' at the edges. Then take three little dishes, which you divide into three sections of flesh colour; have the darkest half again as light as the pink colour, and the other two, each one degree lighter. Now take the little dish of the lightest one; and with a very soft, rather blunt, bristle brush take some of this flesh colour, squeezing the brush with your fingers; and shape up all the reliefs of this face" (Sendler, 2005, p. 242).

The manner in which Panselinos'scolour of the flesh is prepared is also preserved by the painter Dionysius, as follows: "Take lead white - Venetian or French, which is in pieces in papers - and yellow Venetian ocher and, if you don't have Venetian, take another one that resembles it, and a little cinnabar [and, if you want, do not put cinnabar at all because Panselinos did not] (but replace it with bolos). And if you want it (the

\footnotetext{
${ }^{2}$ The most important representative of the School of Thessalonikiwhoworked at the end of the XIII ${ }^{\text {th }}$ century and the beginning of the $\mathrm{XIV}^{\text {th }}$ and came intoprominence as one of the greatestByzantinepainters.
} 
fleshcolour) to be more extinguished, do as follows: grind some cinnabar and add a little of it to the mixture, then leave it to settle down. When it settled down on the bottom of the dish, pour the water into another dish and let the cinnabar dry. Then mix it a little and paint the flesh colour[but don't paint it yellow or white] (Dionysius of Fourna, 2000, pp. 36, 37)".Dionysus of Furna also used a red skin tone, taken over from the Cretan school. He sends it as a recipe calling it another skin colour and describing it as follows: "Take lead white and reddish ocher, and powder them together and prepare the skin colour. If you do not take the reddish ocher, take the other one, the yellow ocher, and mix it with little bolos, to make the mixture reddish. Then, as we wrote above, prepare the skin colour; only take heed, not to make it too red. And if you have Thassosocher, it has no use at all (Dionysius of Fourna,Bucharest, 2000, p. 37).Contrary to this theory, CeninnoCeninni speaks of several stages of phased skintones and about one single light (CenninoCenini, Bucharest, 1977, p. 55).

In the case of the Palaiologanpainting, skin tone is more coloured, with a more apparent yellow-ocher hue. This can be noticed in the image presented that waspainted by Manuel Panselinos, compared with images belonging to the Cretan school. The explanations received through the painting manuals can also stand proof of theadoption of a deeper colour with anadmixture of yellow ocher or Venetian yellow (a highcoverage pigment). In Paleologos painting,skin colour is very important because it is from it that the life and brilliance of the faces that are so evident in this Schoolemanate.

\subsection{The Lights of The Face}

"When you have applied your flesh colours, make another, much lighter one, almost white; and go over the eyebrows with it, over the relief of the nose, over the top of the chin and of the eyelid. Then take a sharp minever brush; and do the whites of the eyes with pure white, and the tip of the nose, and a tiny bit on the side of the mouth; and touch in all such slight reliefs". The so-called lights refer to the lighter tones overlaid on the proplasma (Fig. 1.c.d). They would always be obtained by adding white to the ocherskin tone.

\subsection{The Rosiness of Faces}

The rosiness of the faces is the next step after adding the skin tone, especially in the case of the young characters.In this sense, Dionysius of Fourna stated that "For the faces of Blessed Virgin and the young saints, you ought to put blush in the middle of the face, too thin, mixing cinnabar with the flesh colour. And for the shadows and lines with which you draw the hands, put a very thin layer of bolos. Also, for the elderly, in the deepest wrinkles, put some thin bolos. And the others (skin wrinkles), as many as there are above the eyes (forehead), make them stand out with semi flesh colour..." (CenninoCenini, Bucharest, 1977, p. 55). These recipes for achieving the rosiness of faces were diversified from one era to another, from one school to another. Thus it can be seen that Ceninno recommends putting the rosy hues before the skin tone, i.e. over the proplasma, as follows: "First take a little dish; put a little lime white into it, a little bit will do, and a little light cinabrese, about equal parts. Temper them quite thin with clear water. With the aforesaid bristle brush, soft, and well squeezed with your fingers, go over the face, when you have got it indicated with terreverte; and with this pink touch in the lips, and the 'apples' of the cheeks. My master used to put these 'apples' more toward the ear than toward the nose, because they help to give relief to the face (CenninoCenini, Bucharest, 1977, p. 55).

\section{PIGMENT ANALYSIS}

The pigments used in the composition of face tones from two icons were subject to analysis. The first icon has a green proplasma (PalaiologanSchool) and the second has a warm proplasma inspired by the Cretan school.

The physical and chemical analyses were performed by X-ray fluorescence spectrometry (XRF). The XRF technique is widely used for a first identification of the nature of the pigments used in a painting. It is used in the analysis of the first layers of the areas (Marincaş, laşi, 2003, pp. 26-27). 


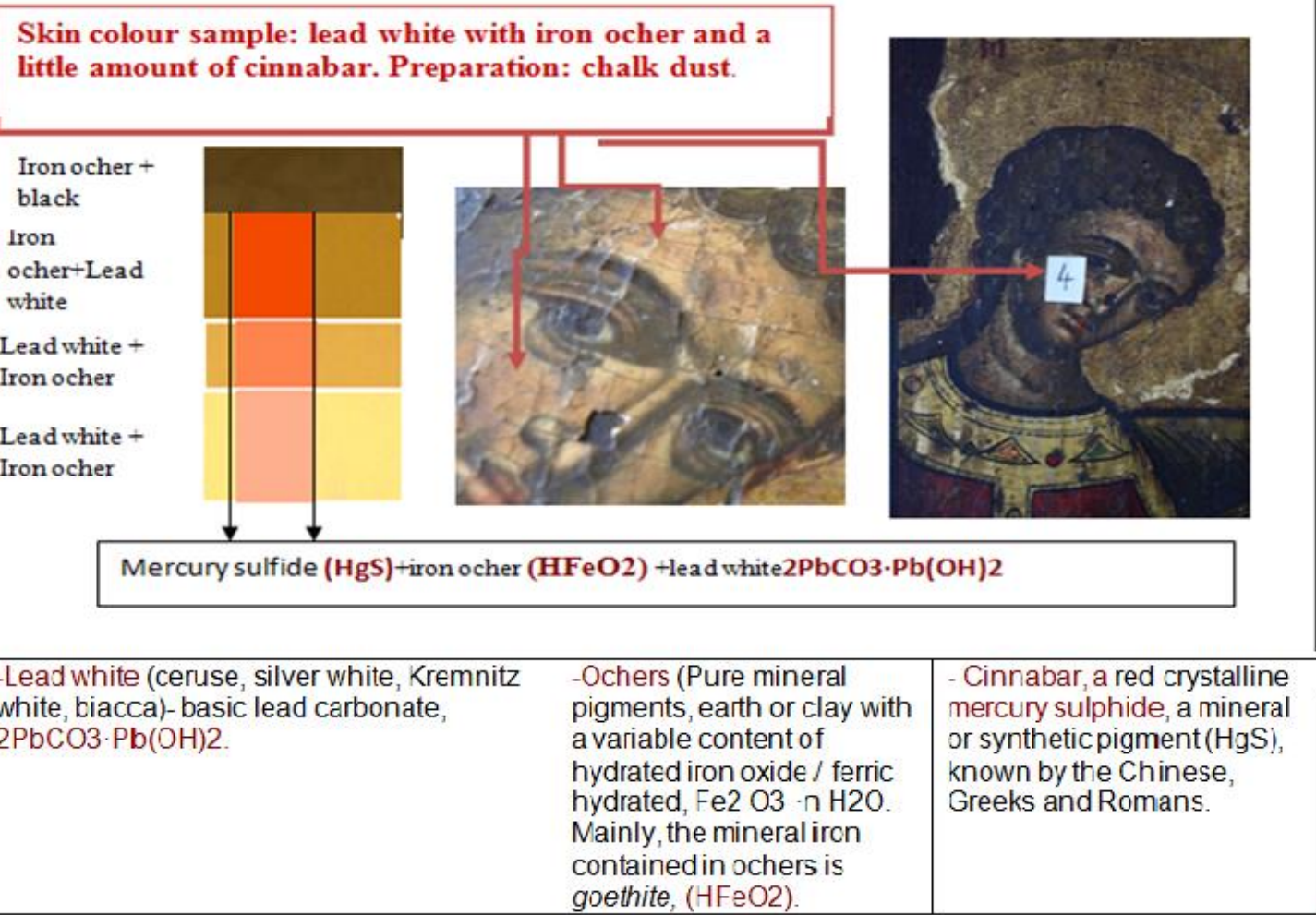

Table 1.Detail from the icon of Holy Mary on the Throne.MănăstireaDintr-un lemn, Valcea, Romania. Chemical and physical analysis of the pigments used in faces.

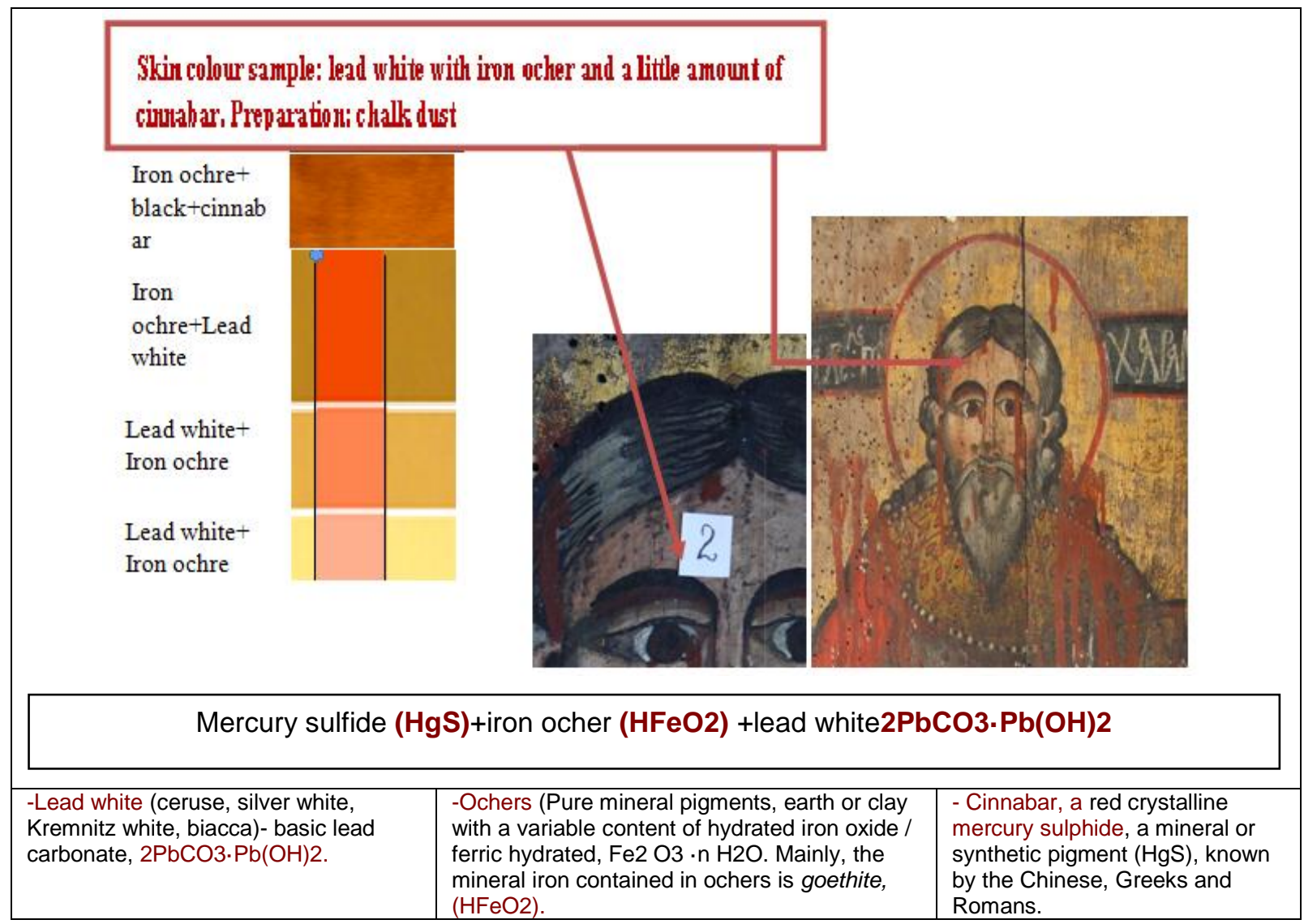

Table 2.Detail from the Icon of St.Haralambie, the Church ofZarnesti, Arges County, Romania Chemical and physical analysis of the pigments used in faces. 


\section{CONCLUSION}

The face in Byzantine painting is represented in its entirety (Cavarnos, 2005, p.17), and, from a technical standpoint, is achieved by overlapping the colour tones, starting with proplasma, skin colour, lights, an exception from this technique being embodied by Teophanes the Greek, who substitutes the flesh colour in some works by applying the lights directly over the proplasma.

In aesthetic terms, two clear directions at the level of theproplasma are traced: the Paleologos painting, which uses green proplasma, and the Cretan painting, which uses red proplasma.

These observations are demonstrated through the analysis of the pigments included in the composition of face, demonstrating the authenticity of the recipes learnt from the painting manuals and books consulted.

These recipes illustrate the fact that both the Palaiologanand the Cretan Schools preserved the technical canons of tonal overlap, the major difference being the recipes at the level of the proplasma, a theory demonstrated by the XRF analysis of pigments as well. Thus, it is demonstrated that in the case of the greenish proplasma, ocher is mixed with black, whilst in the case of the reddish proplasma, cinnabar $(\mathrm{HgS})$ is added to the composition. In the two pieces analyzed, the ocher was the same, namely: iron mineral, with the main content of goethite (HFeO2).

There were, however, exceptions from this phased technique, ever since the late Byzantine period that coincides with the Renaissance in the West. Sometimes, certain stages were neglected, either out of the rush to work the fresco in time or for other reasons, as mentioned by Ceninni. "There are some masters who, at this point, when the face is in this stage, take a little lime white, thinned with water; and very systematically pick out the prominences and reliefs of the countenance; then they put a little pink on the lips, and some 'little apples' on the cheeks. Next they go over it with a little wash of thin flesh colour; and it is all painted, except for touching in the reliefs afterward with a little white. It is a good system. Some begin by laying in the face with flesh colour; then they shape it up with a little verdaccio and flesh colour, touching it in with some high lights; and it is finished. This is a method of those who know little about the profession. But you follow this method in everything which I shall teach you about painting: for Giotto, the great master, followed it" (CenninoCenini, Bucharest, 1977,p.56). In addition to these isolated exceptions in time, the technique has remained unchanged without deviating from the canons of Byzantine painting, being transmitted from master to apprentice with ultimate authenticity.

\section{REFERENCE LIST}

Cavarnos, Constantine, (2005), Ghid de iconografie bizantină, Sophia, Bucharest.

Cennino Cennini, (1977), Tratatul de pictură, Meridiane Bucharest.

Delvoye, Charles,(1976), Arta Bizantină, vol. I, II, Meridiane, Bucharest.

Dionisie din Furna,(2000), Erminia picturii bizantine, Sophia, Bucharest.

Sendler, Egon,(2005),Icoana, chipul nevăzutului, Sofhia, Bucharest.

Marincaş, Octaviana,(2003), Investigaţii ştiinţifice apicate bunurilor de patrimoniu, Performantica, laşi.

Schlumberger, Gustve Leon, (1890), l'Epopee byzantine a la fin dixieme siecle, vol.2, Paris Firmin-Didot, Paris.

Lăzărescu, Liviu,(2009), Culoarea în artă, Editura Polirom, Buchares.

Lothe, A,(1969), Tratate despre peisaj şi figură, Editura Meridiane,Buchares.

Vasiliev, Aleksandr. A, ( 2010), Istoria Imperiului bizantin, Editura Polirom. Bucharest.

Văetişi, Adela, (2008) Arta de tradiție Bizantină în România, Editura Noi, Bucharest.

http://www.crestinortodox.ro/liturgica/pictura/teofan-cretanul-calugar-pictor-98193.html

http://www.crestinortodox.ro/religie/teofan-grecul-iconarul-celor-nevazute-98774.html 